\title{
Territorial Tensions: \\ Rainforest Conservation, Post-Conflict Recovery, and Land Tenure in Liberia
}

\author{
Leif Brottem* and Jon Unruh** \\ *Department of Geography, University of Wisconsin-Madison \\ **Department of Geography, McGill University
}

Since the cessation of the civil conflict in 2003, the Liberian government is poised to expand greatly its protected area network to conserve the country's remaining rainforest. Liberia holds within its borders nearly half of the remaining Guinean rainforest, a global biodiversity hotspot. The planning process for this effort has been a central part of rebuilding Liberia's forestry sector, which helped fuel past conflict. The process, known as the Liberia Forestry Initiative (LFI), is widely considered to have been exemplary with regard to multi-stakeholder dialogue and policy making. Because the issue of land tenure remains widely contested however, the initiative risks seriously aggravating land rights problems, complicating the prospects for a durable peace. This article focuses on the process through which land was zoned for strict protection and how this process is likely to exacerbate land tenure conflict in Liberia's priority conservation areas. Although the international conservation community sees post-conflict scenarios as opportune for promoting conservation initiatives, unresolved land tenure issues make for problematic outcomes, including land disputes and legal disarray. Such problems can result in significant volatility, and can make the peace process and recovery much more, not less difficult. Key Words: Postwar, Liberia, forests, tenure, conservation

"When it comes to the environment, Liberia is a shining example of conservation's role in stability in West Africa."

--Conservation International website 1

The Liberian Forest Initiative (LFI) is a major component of the reconstruction effort undertaken since the end of Liberia's civil conflict in 2003. The post-conflict period has provided a critical window of opportunity for conservationists to develop a transparent and equitable management plan for Liberia's critically important forest resources. Although the country's rainforests were ravaged by years of indiscriminate commercial logging, the country retained 42 percent of West Africa's remaining intact lowland rainforest, which is globally valued for its biodiversity (NFPIS 2006). At the end of the war, much of Liberia's forested areas lacked roads and people, many of whom had been displaced by prolonged violence in rural areas, making these forests significantly attractive for conservation.

When the peace accord was signed, international donor agencies, NGOs, and governments (e.g. Conservation International, UN, USAID, World Bank) immediately began a stabilization and reconstruction effort in Liberia. Following nearly two decades of violence and instability, ongoing reconstruction and reform has taken place in every sector of Liberian society,

\footnotetext{
1 http://www.conservation.org/explore/africa madagascar/liberia/pages/liberia.aspx (last accessed 30 April 2009)
} 
from physical infrastructure to governance (Sawyer 2005). The end of the war was a historic moment when Liberia would be redefined and rebuilt as rapidly as possible, and international agendas regarding peace, economic opportunity and conservation, would be brought to bear.

Land tenure emerges as a central part of the challenge. As a primary factor contributing to the war (Richards 2005; Unruh 2009), land tenure in Liberia has been the basis of violently antagonistic social relations between the state and rural inhabitants, between several ethnic groups, and between generations within chiefdoms. The current President of Liberia has "expressed fear that the issue of land reform, if not swiftly redressed by the government and its international partners, could crop up into another war in the country" (Daygbor 2007). In particular she has noted in recent speeches "that land reform is needed now to contain future troubles", and that "land disputes are a major hurdle in the wake of attaining genuine peace in the country." It was recently estimated that there are several hundred thousand rural youth in Liberia and neighboring Sierra Leone currently vulnerable to militia recruitment, and that "[y]oung people without secure tenancy rights will continue to float in the countryside without stable social commitments, and thus remain vulnerable to both chiefs and militia recruiters" (Richards 2005, 587).

The LFI is a major land reform mechanism encompassing virtually every aspect of the forestry sector through a framework known as the "Three Cs": commercial timber, community forestry, and nature conservation (FDA 2006). The LFI has successfully coordinated the forest sector interventions of an array of Liberian and external governments and agencies. It also included a consultation process with local communities, non-governmental authorities, and other members of civil society. This article concerns the LFI-produced land use plan, which has delimited the entire country into zones designated to meet the conservation, community, and commercial objectives defined through the LFI process. We focus specifically on the planned creation of protected areas that will comprise the core of Liberia's conservation strategy. We argue that the conservation component of the LFI land use plan sows the seeds for future land tenure uncertainty and rural injustice, which were major contributors to the war (Richards 2005; Unruh 2009). We focus specifically on conservation and its linkage to renewed conflict for two reasons: 1) conservation organizations working in Liberia frame their work in contradictory terms: as significant contributors to peace and stability in the country, 2) conservation, more than other land uses, demands territories that are free of people. This demand poses unique problems in Liberia. Large areas of the country that hold conservation value may be perceived as lacking human settlement but this perception opportunistically ignores key aspects of social history and conflict in rural Liberia: notably, large-scale displacement, contested land claims, and fragmented political authority. Liberia represents a confluence of post-conflict land tenure uncertainty, high value forest resources, and the combined use of geospatial technologies and environmental discourses to articulate and legitimize a large-scale exclusionary land use plan.

The article is organized as follows: a methodological and theoretical overview is followed by three analytical sections covering: 1) the role played by remote sensing-based (RS) information and land use modeling in the LFI conservation strategy; 2) how biodiversity and climate change discourses legitimize the land use zones designated by the plan; and 3) the volatility of post-conflict land tenure in Liberia. This volatility will greatly complicate attempts by the central government to impose territory-based land use prescriptions. Such top-down 
impositions, including those with seemingly benign conservation goals, may aggravate rather than reduce the risk of renewed conflict in Liberia.

\section{Methodology}

The field research in Liberia included a series of individual and group interviews and focus group discussions totaling 210 people in the months of December 2006 and February 2007. Those interviewed included smallholder farmers, large landholders, ministry officials, university researchers, NGOs, lawyers, UN personnel, commercial agriculture associations, bilateral and multilateral donors, international legal and development organizations, and a former President of the country (Unruh 2009). The discourse analysis focused on publicly available LFI documents, notably the World Bank Forest Resource Assessment conducted in 2004 and the land suitability analysis carried out in 2006. Interviews with conservation and forest-sector NGOs provided supplemental information.

This article draws from the theoretical tradition in geography of examining the social transformation of nature (Castree 1995; Escobar 1996; Haraway 1997). According to Swyngedouw $(2004,130)$, "nature becomes a sociophysical process infused with political power and cultural meaning." In post-conflict Liberia, this process is manifested through a territorializing project (Vandergeest and Peluso 1995) at a specific scale that is produced through geospatial technology and scientific discourse. Liberia today is a unique case because its specific historical and socio-spatial conditions (shattered political structures and displaced rural populations) that made the LFI project possible also contain the seeds of its undoing. Further, it demonstrates how new scientific discourses, namely climate change mitigation, compound existing ones like biodiversity conservation, to strengthen territorial claims to natural resources without addressing the political legacy of the conflict.

\section{Geospatial Technologies}

Geospatial technologies (remote sensing [RS] tools and geographic information systems) played a critical role in the creation of Liberia's land use plan. By representing and classifying Liberia's landscape in a specific way, these technologies were instrumental in the delineation of future protected areas and other zones in which land use will be prescribed and controlled. Our argument concerning geospatial technologies is based on the following premises: 1) By representing Liberia's forest cover as a gradient of intact dense forest, RS classification implicitly perpetuates the notion of the pristine forest ecosystem, a notion of questionable historical veracity in West Africa (Fairhead and Leach 1998, 2). Classification itself is a political act, whose power is connected to its visibility and to the degree to which it can be contested as a form of knowledge (Bowker and Star 1999, 3). Remote sensing-based land cover information privileges spatio-environmental analysis based on certain types of knowledge and information, namely that which is visually measurable (Turner 2003).

The land use planning component of the LFI relied heavily on a land cover and forest resource assessment produced for the World Bank in 2004. The assessment was based on standard RS analysis of six Landsat scenes from the years 2001-2004. While we do not question the technical rigor of the geospatial analysis, we do question the legitimacy of basing a countrywide land use plan on a set of satellite imagery from a contemporary four-year period. 
The use of contemporary land cover, as classified through RS and scientific discourse, belies a multi-century history of complex population fluctuations and land use patterns in Liberia. As Fairhead and Leach (1998) describe, certain parts of the country were widely assumed to be uninhabited as recently as the $18^{\text {th }}$ Century; however, at least one scholar (Mayer 1951) has compellingly argued that as early as the $17^{\text {th }}$ Century far higher population and far less mature forest cover characterized Liberia.

As Turner $(2003,262)$ argues for the case of the Sahel, the use of a single set of RS information provides a "snapshot of particular times." In the Sahelian case, RS has been used during a time of rapid population expansion that began in the 1950s, leading to neo-Malthusian interpretations of land use change and resource degradation. In the Liberian case, reliance on contemporary RS data provides a land cover snapshot from a period of extreme social dislocation and much reduced population densities in many areas, thereby reinforceing notions of empty and intact forests that are under threat from agriculture and other types of land use.

The classification scheme used in the 2004 assessment reflects this notion of pristine vs. human-disturbed areas in its use of three forest categories: closed dense, open dense (distinguished by signs of recent logging disturbance) and agriculture disturbed. This classification aimed to provide information for the following objectives: country-level land use planning and management; the optimization of forest inventories; and a baseline for land cover monitoring (Bayol and Chevalier 2004). These classes also reflect the objective of measuring forest cover against a previous 1979 inventory known as the Liberia Forest Re-assessment, in order to ascertain change. A compelling aspect of the 1979 inventory, which goes unmentioned in the 2004 Bayol and Chevalier report, is that it was criticized as flawed by a subsequent study conducted in 1985 by the Liberian Forest Development Authority (FDA). The FDA report describes inaccuracies in the 1979 inventory that led to exaggerated estimates of forest loss (Fairhead and Leach 1998, 55). Nonetheless, the 1979 inventory, published by FAO in 1981, was and continues to be deeply influential as demonstrated by its use in subsequent reports and in the LFI.

The 2004 classification and inventory reproduce a narrative of unidirectional forest loss in Liberia whose significant flaws and inaccuracies become invisible, particularly to those without the proper training, knowledge, or the social connections to access and comprehend its contents, as an uncontested baseline of what is recognized as forest cover, exploitable forest resources, and of who may exploit them as dictated through the LFI process. This type of RS classification also privileges visual information that can be detected through satellite imagery (Turner 2003; Walker and Peters 2007). Bayol and Chevalier (2004) acknowledge the difficulty in distinguishing closed and open dense forest at the spatial scale of their analysis, so they relied on the identification of roads as a visual proxy of logging disturbance used to designate areas as open dense forest. This classification decision, based largely on a single visual feature, carries enormous implications for rural Liberians: more than 2.4 million hectares, roughly 25 percent of Liberia's total area, were classified as closed dense forest, which translates into strict protection and land uses from which smallholders will largely be excluded.

The open-closed forest distinction is also critical to the designation of nearly one million hectares for future protected areas. In a 2006 land suitability analysis conducted by a U.S. Forest Service consultant, distance from roads is used as a proxy for "no human settlement" (Nebel 
2006, 5). Land located more than three kilometers from roads is assumed to be uninhabited by people and more than eight kilometers to be free of agriculture. According to the consulting report, Liberian forestry officials confirmed this critical assumption, which is problematic given the oppressive history of state forest services in Liberia and the rest of West Africa (Fairhead and Leach 1998). Although a GIS overlay of human settlements was used in the model, UN refugee data show high levels of displacement around certain areas classified as closed dense forest and officials from two international agencies working in Liberia acknowledged that many forest areas appearing to be uninhabited are likely to be that way as a result of the war. Further, customary land tenure in Liberia, like much of West Africa, extends far beyond the limits of settled areas. Thus while smallholder agriculture, small-scale timber extraction and use of nontimber forest products occur in such areas, more importantly and pervasively is that virtually all land, settled or not, is claimed by indigenous chiefdoms.

Nonetheless, distance from roads and distance to edge of closed dense forest are two of the key variables used to define suitability for conservation because they positively correlate with biodiversity (Nebel 2006, 9). The suitability analysis ultimately produced a map containing 919,930 hectares of zones "optimally" suitable for conservation as twenty-three new protected areas. Strikingly, the conservation suitability analysis mimicked the land cover classifications produced by Bayol and Chevalier (2004) "to a large degree" (ibid, 9). Although the consultant emphasizes that the land use model is a tool that does not provide definitive answers, nevertheless the land use zones produced by the suitability analysis are preserved without change in subsequent forest management documents.

The use of remote sensing-based land cover classes to zone vast areas for protection (and human exclusion) is the fundamental element in the link between conservation and renewed conflict in Liberia. In the final section, we argue that the application of a comprehensive land use plan in the context of Liberia's volatile postwar land tenure situation is a very risky strategy. First, however we examine how remote sensing-based information and knowledge gain power through discourses of biodiversity and climate change mitigation.

\section{Conservation Discourse and Policy}

Globally dominant conservation strategies focus on maximizing the area of land that is: 1) designated as intact habitat (i.e. closed dense forest); and 2) protected through the exclusion of people (see Brandon et al. 1998; Brooks et al. 2002). By producing national-scale maps of land cover that include classifications such as "closed dense forest," RS technologies provide an effective tool that, in conjunction with indicators such as species richness capacity (Defries et al. 2005), is used towards these strategic goals. The policy argument is simple: more intact habitat, more biodiversity.

Climate change mitigation plays an increasingly important role in this logic as national and international policymakers seek large tracts of intact forest in order to sequester atmospheric carbon. Carbon sequestration through "avoided deforestation"2 has been internationally

2 'Avoided deforestation' is the conventional term referring to the ensemble of multi-lateral initiatives that aim to prevent the conversion of tropical forests into other land covers in order to reduce greenhouse gas emissions. 
recognized and Liberia is poised to become one of the first countries to benefit financially through the World Bank-led Forest Carbon Partnership Facility (FCPF). Avoided deforestation dovetails with conservation efforts that seek to maximize permanent intact forest cover. International biodiversity and climate change discourse and policy merge as habitat becomes carbon sink. As the political importance of climate change mitigation increases, the growing attraction of financial capital to forested developing countries such as Liberia only compounds the future risk of land tenure conflict in the country. Advocates for smallholder forest inhabitants in Africa already cite the potential for increased land alienation as a primary risk associated with the UN-led Reducing Emissions from Deforestation and Forest Degradation in Developing Countries (REDD) Programme (Nengo 2008).

The influence of this international conservation policy in Liberia is profound. As part of its goal to maintain the integrity of its forest cover over a twenty-five-year time horizon, Liberia's National Forest Management Strategy of 2007 merged the open dense and closed dense forest classes produced by Bayol and Chevalier (2004) into one category labeled "permanent forest" (NFMS 2007, 11). The new category totals 4.39 million hectares, an equivalent of 47 percent of the nation's territory, including the 919,930 hectares deemed suitable for strict protection, which represents nearly ten percent of Liberia's territory as mandated by the UN Convention on Biological Diversity (UNCBD). The UNCBD, which the Liberian government signed in November 2000, provides the legal anchor for national conservation strategy and the central role played by territorial land use zoning in it.

Liberia's conservation strategy, guided by the UNCBD article on strict territorial protection, reflects the reality that protected areas are one of the "cornerstones" of nature conservation (DeFries et al. 2005, 19). As the previous section demonstrated, the locations and extent of Liberia's future protected areas are heavily influenced by a land cover map that is at best de-contextualized, and at worst part of a flawed narrative of regional deforestation. Despite longstanding efforts to better incorporate people into protected areas (Brechin et al. 2002), the "protectionist paradigm" of conservation is resurging globally and is strongly reflected in Liberia's strategy. According to Hutton et al. $(2005,347)$ this resurgence reflects: "urgency of action, calls to better incorporate biological science in conservation, and the completion of global-scale analysis of biodiversity hotspots." Brandon et al. (1998) argue that "protected areas are the last safe havens for large tracts of tropical ecosystems" (Hutton et al. 2005, 348). As previously noted, justifications for protecting large tracts of land that are classified as intact relate to species richness capacity, which is an accepted measure of a given area's potential to conserve biodiversity (DeFries et al. 2005).

Although grounded in conservation science, the application of species richness capacity in the policy process depends on the highly political and very problematic act of erasing the social history and human-environment interactions from landscapes targeted for conservation (West et al. 2006, 148). This is a necessary step in a two-fold process that transforms landscapes into conservation territories. In Liberia's case, the second step is the creation of a stable land cover category of permanent forest. Although stakeholders can dispute the terms of forest use, its definition and its spatial extent are non-negotiable. Landscapes that were sites of historic struggle, conflict, and dislocation become naturalized spaces to be defined as intact habitat, free of people and strictly protected. 


\section{Postwar Land Tenure}

But because customary land tenure cannot be legislated out of existence, the classification approach sets up extremely contentious relationships about land between the state and rural inhabitants. And because land tenure in postwar Liberia is highly volatile, such relationships detract significantly from efforts within the peace process. Currently the root land tenure problem in the country is the massive confusion that exists on a range of legal, administrative, boundary, claim, and ownership issues. For example, there is confusion about which laws apply where and to whom, there is contradiction within and between laws, there were multiple changes in sub-national boundaries and definitions and roles of administrative areas, and large land areas are simultaneously claimed by chiefdoms, the state, private interests, and informal groups. The link between such confusion and wide-ranging land tenure insecurity and conflict is explicit (Bruce et al. 1994; Unruh 2008), and this link plays a large role in postwar Liberia (Unruh 2009). With little clarity regarding rights, authority, and dispute resolution, a large-scale attempt to redefine land tenure and rezone land use, particularly through territorial exclusion, is perilous.

Approximately half of the country was under the control of armed factions during the 1990 s, and the government is just now coming to understand what has transpired with regard to private, political, and administrative change in land units. The fieldwork revealed that the activities of ex-combatants are a particular problem, some still reporting to militia commanders who engage in a variety of extractive activities (Unruh 2009). The administrative and judicial systems required to handle land matters in the postwar context are currently extremely underdeveloped, nonfunctional, or overstretched. Implementing the wide-reaching LFI land use plan in this socio-political and institutional environment sets up a potentially volatile dilemma.

Post-conflict land tenure and the LFI are embedded in a long history of conquest, claims, and violence that dates to the arrival of the first Americo-Liberians. Armed conflict over land occurred as early as 1822, the year Liberia was established, due to profound conceptual differences in land tenure between Americo-Liberians and indigenous inhabitants (Bruce 2007). With severe suppression of the interior in the early half of the $20^{\text {th }}$ century, the resulting aggrieved socio-political situation grew over time as extensive land appropriation grew into acute grievance, uncertainty, and conflict. By the eruption of the war in 1990, the means acquiring land was had developed into a volatile crisis (Unruh 2009; GRC 2007). Riddell and Dickerman (1986, 102), quoting Liberian expert Gus Liebnow in a personal communication, note that during the Doe regime (1980-1990) "[1] and tenure is at the heart of rural discontent." Subsequent to the war, the Liberian Governance Reform Commission concluded that access to land was a root cause of the armed conflict (GRC 2007). Rural people continue to be skeptical of central authority and it is unsurprising that they are now contesting new territorial claims. Land rights in Liberia after the war are therefore an acute concern (Banks, P., personal communication, December 6, 2006, conversation; Daygbor 2007; Johnson, K., personal communication 12 Feb, 2007, conversation) and the rapid re-assertion of centralized control is risky. An additional concern is the potential reinstatement of certain abuses by customary leadership, particularly with regard to land access for migrant youth. Extremely exploitive arrangements existed prior to 
the war, which fed youth into the militias (IRIN 2007). Indeed "reform of rural rights seems as urgent an issue as tracking the gun-runners or diamond- and timber-smugglers" (Richards 2005, 588).

The general lack of clarity in land rights is aggravated by the existence of the dual tenure system in the country (statutory and customary). There are constant and persistent clashes in Liberia involving customary versus statutory rights over the management, authority, and control of land resources (GRC 2007). The way that this duality functioned was a significant contributor to the war (Unruh 2009).

The fieldwork revealed that effective boundary demarcation is a large and confusing problem. In a number of cases how much land exists in the various counties and concessions is unknown. In others, mistaken numbers are used to calculate such areas (Unruh 2009). In addition, the fieldwork observed that under Liberia's deed system, only the number of acres and approximate boundaries are recorded, and there exists no registry. Complicating this situation is the significant purposeful destruction and alteration of deeds during the war. These issues are all fundamentally important for conservation planning and land inventory. Interviews with members of the Governance Reform Commission (GRC) indicate that there is currently overlap and jurisdictional ambiguity between the state-supported customary units of Clan and Paramount Chieftaincies, and the townships and cities subject to the statutory system. The overall situation is that many boundaries exist in a state of extreme confusion and contestation.

For example, members of the GRC and practicing lawyers estimate that currently up to 90 percent of all cases in all statutory courts are land and property related. Moreover, land disputes are the most frequent cases in local courts (Richards 2005). This is a serious problem after a war when access to justice and the promotion of the rule of law are priorities in the country's peace process (Unruh 2009). At the same time there is a deep distrust of customary courts and their capacity to decide land issues in a fair manner. Interviews with government and customary communities indicate that there is no legal or institutional mechanism whereby disputes and other issues can be resolved between the statutory and customary tenure systems, and that the interface between commercial holdings and smallholder farmers is the focus of increasing conflict (Unruh 2009). A particular example involves whether the Mandingo ethnic group in the north of the country are to be considered citizens of Liberia, and thereby legitimately able to claim and own land. Conflicts are emerging between adverse possession claims via statutory law by Mandingos, and traditional claims by other ethnic groups.

In short, customary land rights that exist within the national-scale land use zones are still highly contested. Significantly problematic with regard to the LFI is that key forests management decisions were finalized in 2007. Although the public consultation phase of the LFI had concluded, important elements of Liberian civil society did not fully support the management plan, as indicated in an open letter signed by fourteen Liberian and seven international NGOs on 25 September 2006. The letter states clearly that the Forestry Reform Law, adopted on 19 September 2006, failed to address community land tenure, access and user rights, or meaningful public participation in forest management and sector reform. Nearly two years later, the NGO coalition of Liberia issued a statement in July 2008 identifying three timber contracts issued by the FDA that violate the property rights of local communities. Allegedly the government was fully aware of existing community land claims but chose to ignore its own policy. The statement 
further describes a larger problem that the reform process and rule of law in the forestry sector are at risk due to opaque procedures.

\section{Conclusion}

Liberia's land use planning process was made possible by the presumed "clean slate" that was the country's rural landscape following the end of hostilities. Although rural Liberia was dangerous and unstable, it was a clean slate in the sense that no customary authorities could counter the territorializing affects of post-war land use planning. Actors seeking to control Liberia's vast and valuable forest resources, including its biodiversity and potential to sequester carbon, have used geospatial technologies and scientific discourse as tools to establish a system of territory-based authority covering the entire country. We have argued, however, that this project ignores issues relating to a problematic political and scientific discourse, technology application, and land tenure at considerable peril.

\section{References}

Bayol, N., and J. Chevalier. 2004. Current state of the forest cover in Liberia. Washington DC: World Bank.

Bowker, G., and S. L. Star. 1999. Sorting things out: Classification and its consequences. Cambridge, MA: MIT Press.

Brandon, K., K. Redford, and S. Sanderson. 1998. Parks in peril: People, politics, and protected areas. Washington DC: Island Press.

Brechin, S., P. Wilshusen, C. Fortwangler, and P. West. 2002. Beyond the square wheel: Toward a more comprehensive understanding of biodiversity conservation as social and political process. Society \& Natural Resources 15 (1): 41-64.

Brooks, T., R. Mittermeier, C. Mittermeier, B. da Fonseca, A. Rylands, P. Konstant, and J. Flick. 2002. Habitat loss and extinction in the hotspots of biodiversity. Conservation Biology 16: $910-23$.

Bruce, J., and S. E. Migot-Adholla. 1994. Searching for land tenure security in Africa. The World Bank and Kendall/Hunt: Dubuque, IA.

Bruce, J. 2007. Insecurity of land tenure, land law and land registration in Liberia: a preliminary assessment. Washington DC: The World Bank.

Castree, N. 1995. The nature of produced nature: materiality and knowledge construction in Marxism. Antipode 27: 12—48. 
Daygbor, J. 2007. Land dispute-country's next war trigger. The Analyst (Monrovia) All Africa Global Media. Monrovia. 21 March. http://allafrica.com/stories/200703210858.html (last accessed 1 May 2009).

DeFries, R., A. Hansen, A. Newton, and M. Hansen. 2005. Increasing isolation of protected areas in tropical forests over the past twenty years. Ecological Applications 15 (1): 19-26.

Escobar, A. 1998. Whose knowledge, whose nature? Biodiversity, conservation, and the political ecology of social movements. Journal of Political Ecology 5: 53-82.

Fairhead, J., and M. Leach. 1998. Reframing deforestation: Global analysis and local realities: studies in West Africa. London: Routledge.

Governance Reform Commission (GRC) 2007. The way forward: land \& property right issues in the Republic of Liberia. Governance Reform Commission, Monrovia: Government of Liberia.

Haraway, D. 1997.Modest-witness@second-millennium.FemaleMan-Meets_OncoMouse. London: Routledge.

Hohe, T. 2005. Developing local governance. In Postconflict development: Meeting new challenges, eds. G. Junne, and W. Verkoren, 59-72. Boulder: Lynne Reinner.

Hutton, J., W. Adams, and J. Murombedzi. 2006. Back to the barriers? Changing Narratives in Biodiversity Conservation. Forum for Development Studies 32 (2): 341—70.

IRIN. 2007. Liberia: donor fatigue threatening DDR process. New York: UN Office for the Coordination of Humanitarian Affairs.

Internal Displacement Monitor. 2007. Facilitated return of Liberian IDPs by county. Geneva: UNHCR.

Junne, G., and W. Verkoren. 2005. The challenges of postconflict development. In Postconflict development: Meeting new challenges, eds. G. Junne, and W. Verkoren, 1-18. Boulder: Lynne Rienner.

Mayer, K. 1951. Forest Resources of Liberia. Washington DC: U.S. Department of Agriculture.

Nebel, M. 2006. GIS for land use planning in Liberia-delineation of land use areas. Liberia Forest Initiative. http://www.fao.org/forestry/29662/en/ (last accessed 30 April 2009).

Nengo, E. 2008. Dialogue between the World Bank and indigenous peoples in Central and East Africa on the forest carbon partnership facility. Bujumbura, Burundi: UNIPRPOBA-IPACC. 
Plunkett, M. 2005. Reestablishing the rule of law. In Postconflict development: Meeting new challenges, eds. G. Junne and W. Verkoren, 73-98. Boulder: Lynne Rienner.

Republic of Liberia Forestry Development Authority. 2006. National forestry policy and implementation strategy: Forestry for communities, commerce, and conservation. Monrovia: Forest Development Authority of Liberia.

Republic of Liberia Forestry Development Authority. 2007. National forest management strategy (draft). Monrovia: Forest Development Authority of Liberia.

Richards, P. 2005. To fight or to farm? Agrarian dimensions of the Mano River conflicts (Liberia and Sierra Leone). African Affairs 105: 571—590.

Riddell, J., and C. Dickerman. 1986. Land tenure profile: Liberia. In Country Profiles of Land Tenure: Africa 1986. eds. J. Riddell, and C. Dickerman, Madison, WI: Land Tenure Center, University of Wisconsin, Madison.

Sawyer, A. 2005. Beyond Plunder: Toward Democratic Governance in Liberia. Lynne Rienner Publishers: London.

Swyngedouw, E. 2004. Scaled geographies: Nature, Place, and the Politics of Scale. In Scale \& geographic inquiry: Nature, society, and method. eds. E. Sheppard, R. McMaster, 129153. Oxford: Blackwell Publishing.

Turner, M. 2003. Reflections on the use of remote sensing and geographic information science in human ecological research. Human Ecology 31 (2): 255-79.

Unruh, J. 2008. Toward sustainable livelihoods after war: reconstituting rural land tenure systems. Natural Resources Forum 32: 103-115.

-----2003. Land tenure and legal pluralism in the peace process. Peace and Change: A Journal of Peace Research 28: 352-376.

------2009. Land rights in postwar Liberia: the volatile part of the peace process. Land Use Policy 26: $425-433$.

Vandergeest, P. and N. Peluso. 1995. Territorialization and state power in Thailand. Theory and Society 24 (3): $385-426$.

Walker, P., and P. Peters. 2007. Making Sense in Time: Remote Sensing and the Challenges of Temporal Heterogeneity in Social Analysis of Environmental Change - cases from Malawi. Human Ecology 35 (1-2): 69—80. 
West, P., Igoe, J., and Brockington, J. 2006. Parks and peoples: The social impact of protected areas. American Review of Anthropology 35: 251-316.

\author{
Leif Brottem \\ Department of Geography \\ 550 N. Park Street \\ University of Wisconsin-Madison \\ Madison, WI 53703 \\ Phone: (608) 262-2138 \\ Fax: (608) 265-3991 \\ brottem@wisc.edu
}

Jon Unruh

Department of Geography

805 Sherbrooke St. W.

McGill University

Montreal, Quebec

H3A 2K6 Canada

jon.unruh@mcgill.ca 